\title{
Women Empowerment through Muslim Architecture Which Built by Name of them in Bangladesh during Mediaeval Period: A Preliminary Survey Report
}

\author{
Sk. Zohirul Islam ${ }^{1}$ \\ ${ }^{1}$ Research Assistant, Center for Heritage Studies (CenHerSt), Dinajpur, Bangladesh \\ Correspondence: Sk. Zohirul Islam, Research Assistant, Center for Heritage Studies (CenHerSt), Dinajpur, \\ Bangladesh. Email: zohirul.cenherst@gmail.com \\ To cite this article: Islam, S. Z. (2018). Women Empowerment through Muslim Architecture Which Built by Name \\ of them in Bangladesh during Mediaeval Period: A Preliminary Survey Report. American Economic \& Social \\ Review, 3(1), 12-17. Retrieved from http://www.cribfb.com/journal/index.php/aesr/article/view/195
}

Received: November 1, 2018

Accepted: November 3, 2018

Online Published: November 10, 2018

\begin{abstract}
There are many Muslim architectures built by women patron which called Bibi/Begum in Bangladesh during mediaeval period as Binat Bibi Mosque architecture at Dhaka. It mentioned women's contribution financially. This research paper is trying to show women empowerment through architecture which built by name in Bangladesh during mediaeval era. It is a preliminary qualitative survey report and tries to understand how housewives inspired to makes/commissioned for constructing monuments. Besides, what was the position of them in the Royal court or their society as well as Bibi/Begum contribution in mediaeval Muslim mosque architecture of Bengal and by name monuments of tomb architecture formation?
\end{abstract}

Keywords: Women, Bibi/Begum, Architecture, Bangladesh, Muslim, Mediaeval, Contribution.

\section{Introduction}

The mosque architecture of Bangladesh attract all scholar in view of architecturally and thus various article and books published about it in the subcontinent. But a few numbers noticed in the above-mentioned subjects. Although it is a very interesting fact and also it has socio-economic discourse. Bibi and Begum are the honor addressed to married women in Bangla Language which word come from Arabic-Farsi Language. For this reason, the aim of this feature is to introduce the women contribution and patronage of the monument of the mediaeval Bengal, where we get that what was the position of them in contemporary society? Yet some tomb architecture built by their father or husband after them died for beloved like Taj Mahal. Furthermore, mosques and madrasas have been financed and constructed by richly person contribution or ruler patron and on the other hand, someone maintains their piety and Social Status. And in addition, some contributing happened by the ruler or social elite, such a monarch, a prince or queen, a religious or pious women leader, a women landowner etc. Especially, the building of a mosque was mentioned to be a charitable act according to the Quran (4:7-12,176), which one indicates of the religious sacrifice work. However, we have been found 17 (Seventeen) number mosques architecture and 8 (Eight) numbers tomb monuments, which were related to Bibi and Begums name i. e. women name. That indicates to women empowerment in Muslim rule of Bangladesh. 


\section{Name of the Patron}

We have been found 18 women patron name in this survey as follows: Binat Bibi, Bibi Begani, Rajbibi, Bibi(Unanimous), Bibi Marium, Bibi Marium Saleha, Ladli Begum, Jongi Bibi, Bibi Meher, Lattan, Bibi Chini, Bibi Champa, Bibi Marium, Azim al-Nisa Begum, Badr Nisa Begum, Minia Bibi, Shaha Banu Begum, Nusairi Begum. Actually, Bibi is an Arabic word and it means lady/a man's wife. Bibi means Miss in Urdu and is frequently used as a respectful title for women in South Asia when added to the given name. Bibi like Begum is used as a surname by some Bangladeshi and Pakistani women and baigum or beygum in Turkish.

3. Name of the Mosque Monuments List

- Bibi Begani Mosque, Bagerhat District, $16^{\text {th }}$ century.

- Rajbibi Mosque, Gaur (present West Bengal).

- Binat Bibi Mosque, Narinda, Dhaka District.

- Bibi Mosque, Sherpur, Bogra District.

- Bibi Marium Mosque, Narayanganj.

- Bibi Marium Saleha Mosque, Nilkhet, Dhaka District.

- Ladli Begum Mosque, Begum Bazar, Dhaka District.

- Jongi Bibi Mosque, Dhaka District.

- Bibi Meher Mosque, Dhaka District.

- Lattan Mosque, Gaur (present West Bengal).

- Jahaniyan Mosque, Gaur (present West Bengal).

- Bibi Chini Mosque, Patuakhali District.

- Azim al-Nisa Begum Mosque, Murshidabad, PashimBangla.

- Badr Nisa Begum Mosque, Murshidabad, PashimBangla.

- Shaha Banu Begum, Tallyganj (Kolkata), PashimBangla.

- Nusairi Begum Mosque, Murshidabad, PashimBangla.

- Chak Mosque, Murshidabad, PashimBangla.

Name of the Tomb Architecture List

- Bibi Champa Tomb, Dhaka District.

- Bibi Marium Tomb, Dhaka District.

- Paribibi Tomb, Dhaka District.

- Dara Begum Tomb, Dhaka District.

- Begum Bibi and Guljer Begum Tomb, Dhaka District.

- Minia Bibi Tomb, Murshidabad, PashimBangla.

\subsection{Binat Bibi Mosque, Dhaka (Photo 1)}

Binat bibi mosque (1456-57 A.D.) inscription to giving information about Binat Bibi, i. e., the donor, who was Musammat Bakht Binat, daughter of Marhammat. There is no another information about the ruling king or sultan. The mosque is situated in Narinda under Sutrapur Polis Station at Dhaka of Bangladesh. The inscription is giving the date of construction and provide information about the contribution or patron. Sometimes patron was sultans and other patrons were ruling king, the official of the sultan, religious saint or scholar, women sponsorship etc.

3.2 Bibi Begni Mosque, Bagerhat

There is no inscription. This mosque situated in the village of Chunakhola about $200 \mathrm{~m}$. west of a huge tank known as Ghoradighi at Bagerhat district of Bangladesh. The building is attributed to Bibi Begni, locally believed to have been Khan Jahan's wife (Perween Hasan, 2007:123). The name of the mosque recommends that it belonged to a Bibi Begni, whose identity is ambiguous. One local tradition imputes her as one of Khan Jahan's wives, while another makes her a concubine of khan jahan, who erected this building over her grave.

3.3 Bibi Chini Mosque, near Niamati, Betagi, Patuakhali, 16th Century AD

This mosque built by Bibi Chini, who is said to be the sister of Niamatullah, the founder of a large settlement at Niamati. It must be dated from the pre-Mughal period.

3.4 Dara Begum Tomb and Bibi Masjid (Photo 4)

Tomb of Dara Begum (middle of the $17^{\text {th }}$ Century A.D.) and Dara Begum's Mosque building is situated near Lalmatia Women's College of Mohammadpur, Upazila Mohammadpur (Thana), Dhaka District.

3.5 Begum Bibi and Gulzar Bibi

Tombs of Begum Bibi and Gulzar Bibi (17 ${ }^{\text {th }}$ Century A.D.) is situated in Dhaka of Bangladesh. 


\subsection{Tomb of Pari Bibi, 1684 A.D. (Photo 3)}

The most attractive as well as well-preserved architectural monuments in the Lalbagh fort is undoubtedly the Tomb of Bibi Pari, who was the daughter of Shaista Khan and wife of Prince Muhammad Azam. Bibi Pari suddenly died in 1684 A.D.

3.7 Bibi Masjid, 1628 A.D.

The Bibi Masjid, which was built according to an inscription by Sayyid Ali Mutawalli during the reign of Sha Jahan in the year 1628 A.D., is a small and unpretentious building and situated in Sherpur of Bogra District. Towards the south of the Khodkartola Masjid lies Bibi Masjid. It likewise conforms to the single-domed type of mosque. It is said that the daughter of Raja Balaram fell in love with Ghazi shah Madar but as the Raja refused to give her daughter in marriage to the Ghazi, she remained unmarried and came to be known as Bibi. Shah Madar also remained bachelor.

3.8 Bibi Meher Mosque, 1814 A.D., Narinda, Dhaka

According to an inscription hung up over the central archway. It was built by Bibi Meher, who was presumably a relation of Ghulam Muhammad in A.H. 1230/1814 A.D. It is a single domed square mosque. A little to the south east of Ghulam Muhammad's Gateway in Narinda is a beautiful structure of considerable architectural posturing.

3.9 Jahaniyan Mosque

The jahaniyan mosque in Gaur is a six domed structure construction just before Sher Shahs conquest of Bengal. It was built during the reign of Ghiyatuddin al-din - Mohammad shah by Bibi Malti. (Elizabeth schotter Merklinjar, 2005: 66).

3.10 Muni begum

Muni begum is the patron of the Chawk Mosque (1181 AH / 1767 AD). It is seven bayed large mosque, situated in the center of Murshidabad at west Bengal. It is identified in the inscription as Muni Begum was the highly influenced wife of Nawab Mir Jaffar. It was constructed in 1767 A.D. under the supervision of sheikh khalil Allah. (Michell, 1984:87).

3.11 Lattan Mosque

On the name Lattan, Alexander Cunninghum observed that the name of this Mosque is universally believed to be derived from Nattu, a famous dancing girl of the king, after whom it was called the nation masjid or as it is more generally pronounced, the lattan masjid. Abid Ali also records that there is a local tradition that the mosque was built by a dancing girl who, being a favorite of some king. Acquired much wealth all the money she has as meritorious work. She concealed her name and put the kings' name in the inscription tablet, the originally meaning of the word is a tumbler pigeon. (Ahmed hasan dani, 1961:120-121).

\subsection{Rajbibi Mosque (15th Century AD)}

The Rajbibi Mosque is a small elegant monument in Gaur. Someone, which is called khaoria Dighi. Actually the local people is Called it Rajibibi Mosque. Literally, Rajbibi means Royal (Raj) Lady (Bibi). Presumably it was built by a prominent member of the Harem of the Bengali Sultans. Though there is no inscription has been assigned to it. 3.13 Bibi Mariyam Masjid, Narayanganj District (Photo 2)

Bibi Maryam Masjid translated in English as Lady Mary Masjid, is a masjid situated in the Killarpur area of Narayanganj district in Bangladesh which was built under the period of Mughal intervention in around 1680 A.D. She was actually wife of Eisha Khan.

Besides, there have been found some monuments which are built during the Nawabs basically in Murshidabad area as follows: Azim al-Nisa Begum, Badr Nisa Begum, Minia Bibi Tomb, Shaha Banu Begum, Tallyganj (Kolkata), Nusairi Begum, Chak Mosque. Murshidabad was founded in 1704 before which Dacca (now Dhaka) was the capital of the subah or province of Bengal (Present Bangladesh and Paschim Bangla), including Bihar and Orissa. By 1757 after the eclipse of Nawab Siraj-ud-Daula, Murshidabad's political importance rapidly diminished and by 1790 all administrative infrastructure of the state was transferred by the British to their capital city Calcutta. However, culturally and especially for its arts and crafts of Murshidabad and its environs continued to flourish well into the 19 th century.

\section{Discussion}

Power always has been in the laying with dominators and will be in their hand, may or may not. When language is changing, in the same way, the hand of the dictators will change in society. Thus women society do flourish of her work and activities up to far away and her speed is coming into the act of social welfare through to cultural religious way. For this reason, we found the vast contribution of women for making or edifice of the mediaeval Muslim Mosque architecture of Bangladesh. That was the progressivization of women in Bangladesh (past Bengal) during 
15 th to 18th century there has other politicalize women figure, as for example Mughal princess Nurjahan and Sultana Razia etc. We know that there mostly inscription has been written a Hadith, which is "Whoever builds a mosque in the world, Allah will build forty palaces (for him) in the paradise." For this reason, they (women) had been inspired those verses to build mosque and women's endowment contributed to building Mosques like the ruler, elite class people, and merchants.

Doubtless, all are high ranking lady belonging to the royal family. Though one of them is a royal concubine of Mir Jaffar of Bengal Nawab and another one dancer or unknown women etc. Beside these another Mosque name are Jahaniyan Mosque in Gaur (1535 A.D) and Lattan Mosque (late fifteenth and early sixteenth century) in Gaur, which attire constructed by Bibi Malti and noble women dancer (Lattan /Nati).

5. Conclusion

The Muslim architecture of Bangladesh is not only magnificent but also it gave traditional and richly sophisticated forms of Islamic art, architecture, and culture. With women empowerment, where we followed as practiced of the royal ranking lady and highly aristocratic women patronize for the build to the mosque. Socially, the most and important result of the women patron was the developed women rights through to Islamic Sharia law. It is true that in the above mentioned architectural elements had settled in Bangladesh and West Bengal during mediaeval period as feminism outlook. Moreover, we need to further study this matter including West Bengal content also.

\section{References}

Abid Ali Khan (1931), Muhammad. Memoirs of Gaur and Pandua. Edited and revised by H. £. Stapleton. Calcutta, Bengal Secretariat Book Depot.

Ahmed, Nizamuddin (1980), Bagerhat Monuments. Dacca, Department of Archaeology and Museums. Ahmed, Shamsud-Din (1960), Inscriptions of Bengal, Vol. IV. Rajshahi, Varendra Research Museum. Aulad Hasan (1904), S. Notes on the Antiquities of Dacca, Calcutta, M. M. Baysak.

BANERJEE, B. N. (1942), Begums of Bengal. Calcutta, S. K. Mitra.

Dani, A. Hasan. (1961), Muslim Architecture in Bengal, Dacca, Asiatic Society of Pakistan.

Hasan, S. M. (1979), Mosque Architecture of Pre-Mughal Bengal. 2nd ed. Dacca, University Press Ltd. . (1980), Muslim Monuments of Bangladesh. 2nd ed. Dacca, Islamic Foundation of Bangladesh.

Kljraishi, M. H. (1931), List of Ancient Monuments Protected Under Act Vll of 1904 in the Province of Bihar and Orissa. Archaeological Survey of India, New Imperial Series, Vol. LI. Calcutta, Government of India, Central Publication Branch.

(1896), List of Ancient Monuments in Bengal. Revised and Corrected Up to 31st August 1895. Prepared by the Government of Bengal, the Public Works Department. Calcutta, Bengal Secretariat Press.

Joseph David. (1888), Archaeological Survey of Bengal: Report for 1888. Calcutta, Catholic Orphan Press.

Michell, George (Ed.). (1978), Architecture of the Islamic World: Its History and Social Meaning. London, Thames \& Hudson.

Michell, George (Ed.). (1984), Islamic Heritage of Bengal, UNESCO.

O'MALley, L. S. S. (1914), Murshidabad. Vol. 32 of Bengal District Gazetteers. Calcutta, Bengal Secretariat Book Depot.

Ravenshaw, John Henry, (1878), Gaur: Its Ruins and Inscriptions. London, Kegan Paul.

Ray, R. N. Bengal Nawabs. Calcutta, Victoria Memorial, n.d.

Taifoor, Syed Muhammad. (1956), Glimpses of old Dacca. 2nd ed. Dacca, S. M. Pervez.

Elizabeth schotter Merklinjar, (2005), Sultanate Architecture of pre -Mughal India, Munsihram, Delhi. Perween Hasan, (2007), Sultans and mosques: The early Muslim architecture of Bangladesh, New York. 


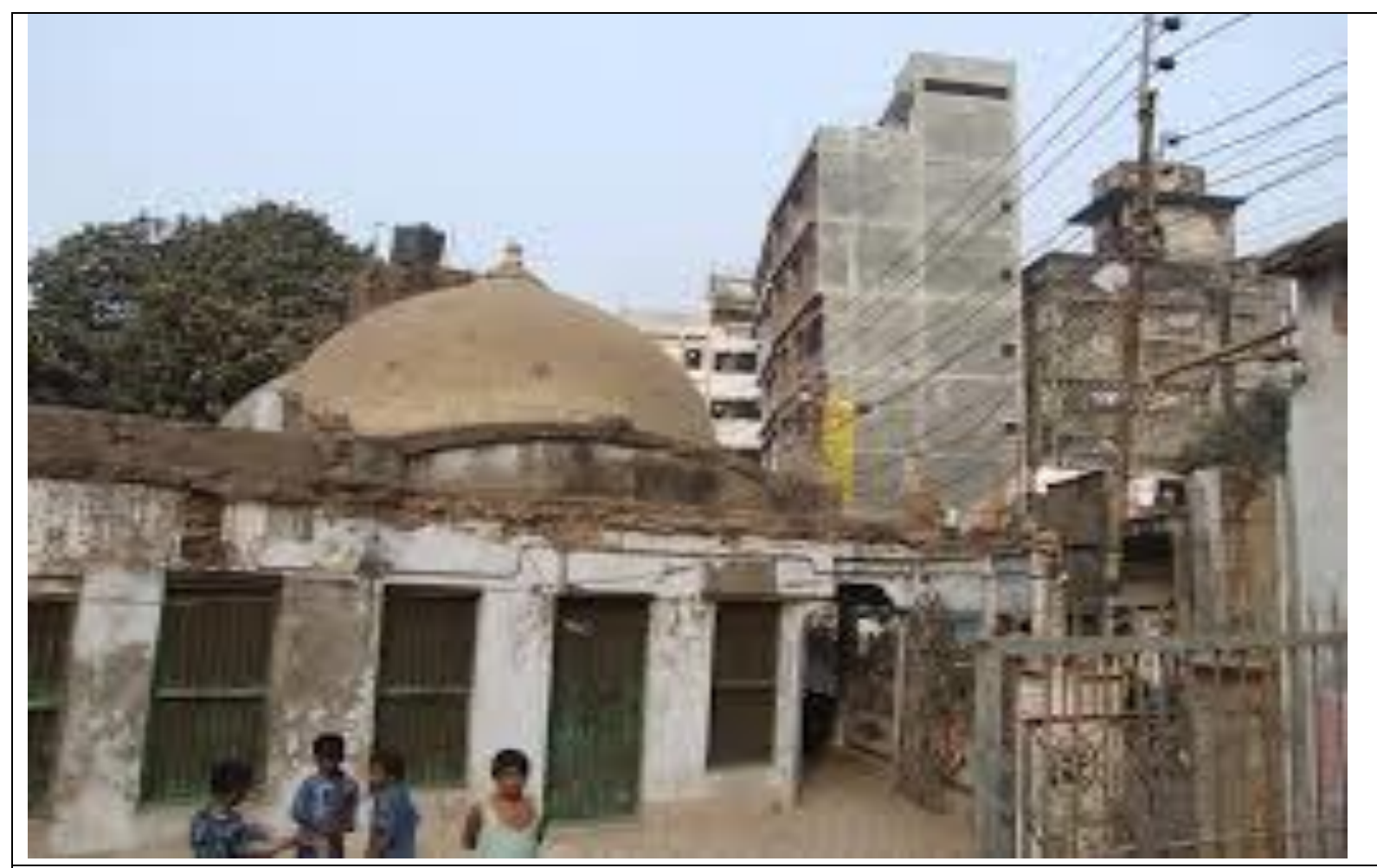

Photo 1: Binat Bibi Mosque.

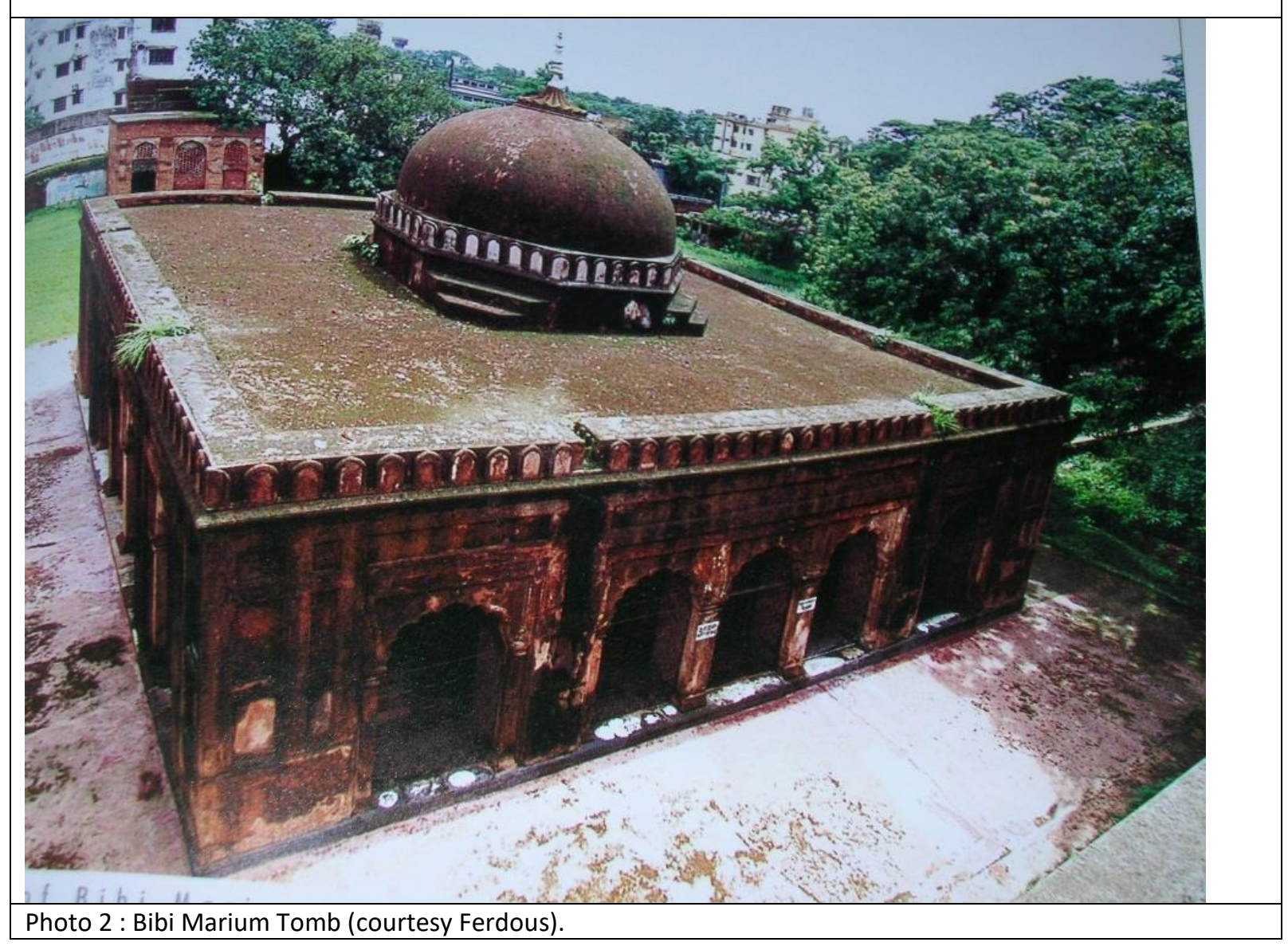




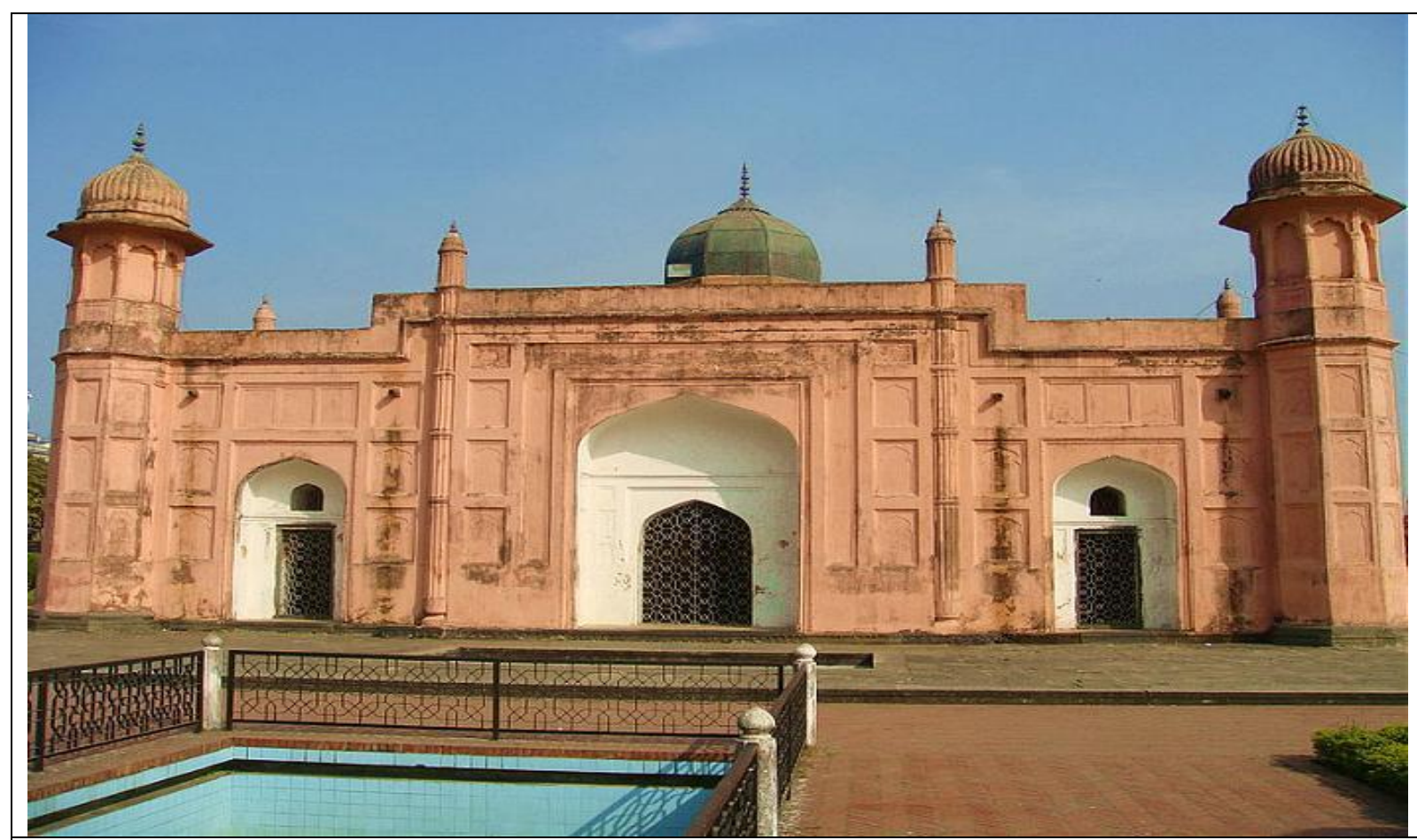

Photo 3 : Tomb of Pari Bibi, Dhaka (courtesy, taken from internet).

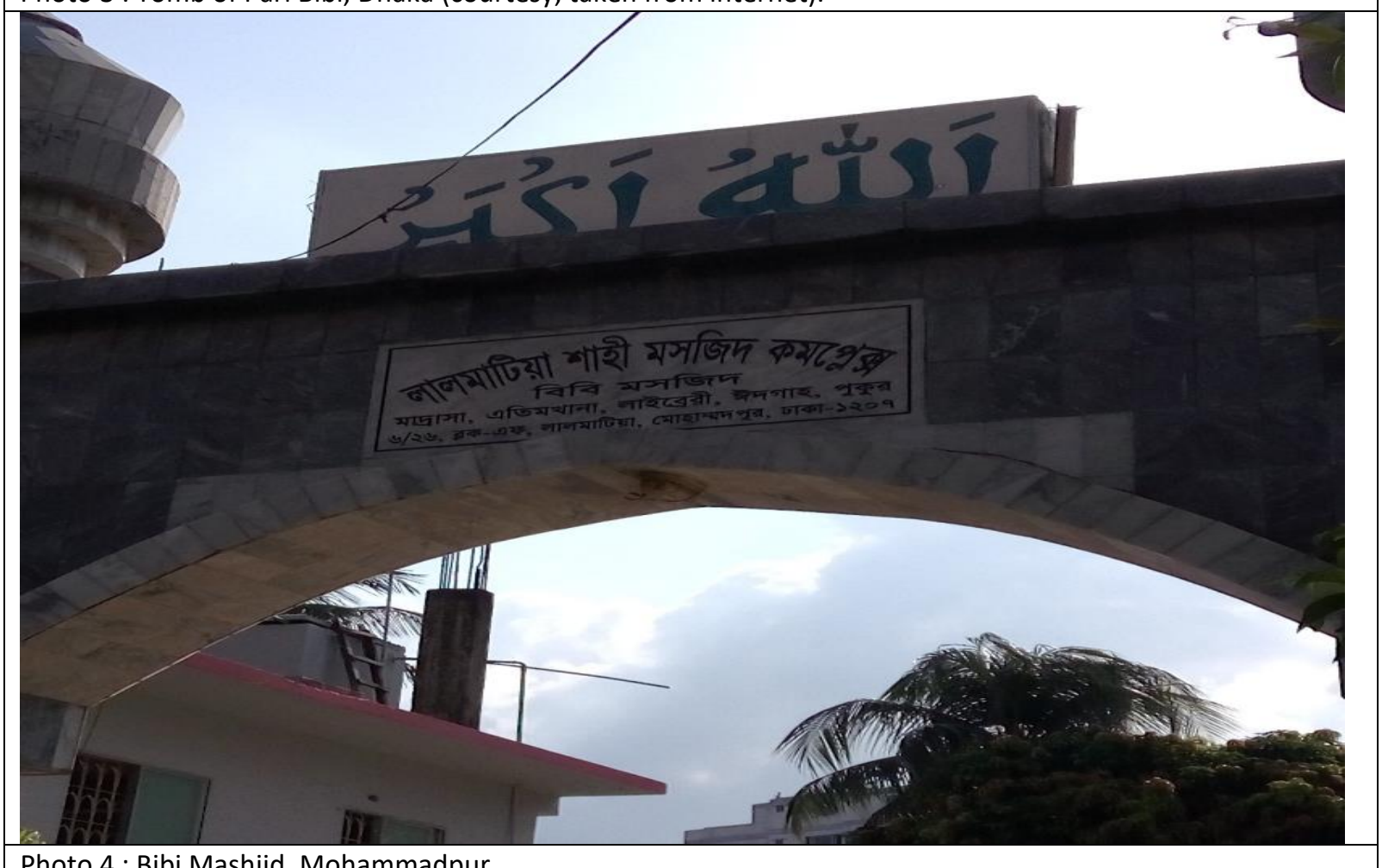

Photo 4 : Bibi Mashjid, Mohammadpur.

\section{Copyrights}

Copyright for this article is retained by the author(s), with first publication rights granted to the journal. This is an open-access article distributed under the terms and conditions of the Creative Commons Attribution license (http://creativecommons.org/licenses/by/4.0/) 